\title{
IMPACT OF TRANSFORMATIONAL LEADERSHIP, PERSONALITY AND JOB INVOLVEMENT TO ORGANIZATIONAL CITIZENSHIP BEHAVIOR
}

\author{
NiningDwirosanti \\ Ministry of Education and Culture Republic of Indonesia \\ ndrosanti@gmail.com
}

\begin{abstract}
The purpose of this study examines the impact of transformational leadership, personality, job involvement to organizational citizenship behavior $(O C B)$ structural officials directorate general of teachers and education personnel of the ministry of education and culture. The research used quantitative method with survey approach. Research sample of 123 structural officials of echelon 4 are taken at random. Collecting data using questionnaires and data analyzed using path analysis. The results showed: transformational leadership had a direct positive and significant effect on $O C B$; personality had a direct positive and significanton $O C B$; And job involvement has a direct positive and significant effect on OCB; Transformational leadership has a direct positive and significant impact on job involvement; Personality has a direct positive and significant effect on job involvement; Transformational leadership has a direct positive and significant effect on the personality. Thus, in order to increase OCB to structural officials in the directorate general of teachers and education personnel environment, transformational leadership, personality, and job involvement need to be improved.
\end{abstract}

Keywords: Transformational leadership, personality, job involvement, organizational citizenship behavior.

One of the most decisive things for organizations lies in the organizational citizenship behavior (OCB) of its members. OCB is the willingness of members of an organization to act outside its formal role for the progress of the organization, successfully exceeding the targets or standards set by the organization. High OCB is demonstrated through behavior in the form of altruism, consciousness, sportsmanship, courtesy, and civic virtue. Thus, behaviors that reflect OCB may secure the organization, move forward the organization, and create a quality work life that is conducive to every member of the organization. Leadershipbehaviors are needed by an organization to develop its organization optimally. Especially for public organizations such as government which its excellent services are the priority to the community, OCB is very important and needed. It also occurs in the Directorate General of Teachers and Education Personnel Ministry of Education and Culture Republic of Indonesia. As a work unit of the Government under the auspices of Ministry of Education and Culture, the Directorate General of of Teachers and Education Personnel also provides public services to the public, especially those related to the development and empowerment of teachers and education personnel. That is, the role of Directorate General of Teachers and Education Personnel is very strategic in an effort to prepare superior and qualified teachers and education personnel. The results of a survey conducted by the secretariat of the Directorate General of Teachers and Education Personnel with three heads of department leaders indicate that the structural officials at the head section of the section (echelon IV) generally these officials work by using the assigned function task without thinking how to give the best to their organization. Not a few officials who work less care of the principle of prudence, lack of helpful attitude, less sporty in facing the problem, and less prudent in making decisions related to his work. This reflects the limited organizational citizenship behavior (OCB) of the Directorate General of Teachers and Education Personnel which is interesting to be studied, especially through the perspective of transformational leadership, personality, and job involvement. 
Based on the background of the problem, problem identification are: (1) Does transformational leadership have direct influence on OCB officials? (2) Does personality have direct influence on OCB officials? (3) Does job involvement have direct influence on OCB officials? (4) Does personality have direct influence on the job involvement officials?

\section{Research Methods}

This research uses quantitative approach or positivistic paradigm. Quantitative research is related to survey techniques, such as questionnaire distribution, experimentation, structured observation, statistical analysis. Themethod is a survey method, research aimed at assessing large and small populations by selecting and reviewing selected samples from the population to find the incidence, distribution, and relative interrelations of the variables. Specifically, surveys are used to study attitudes, beliefs, values, demographics, behavior, opinions, habits, desires, ideas and other types of information. From the data, the facts or the information can then be conditioned of each variable that researched allowing to know the correlations of one variable to another variable, which in the context of this study is the impact of transformational leadership, personality, and job involvement as exogenous variables and OCB as Endogenous variables.

This research used questionnaire distribution method of collecting data, includes data of: transformational leadership, personality, job involvement, and OCB collected through questionnaire distribution. Questionnaires are designed using Likert scale and rating scale. On this scale the proposed statements are supplemented with five alternative answers and their weightings for each alternative.

\section{Research Results}

Based on the results of data processing using SPSS data obtained are as follows:

Table 4.12Summary of Path Coefficient and Test $\mathrm{t}$

\begin{tabular}{|c|c|c|c|}
\hline \multirow{2}{*}{ Line } & \multirow{2}{*}{ Coefficient } & \multirow{2}{*}{ Tcount } & Ttabel \\
\cline { 4 - 4 } & & & $\mathbf{\alpha = 0 , 0 5}$ \\
\hline Py1 & 0,383 & $5,772^{*}$ & 1,980 \\
\hline Py2 & 0,232 & $3,142^{*}$ & 1,980 \\
\hline Py3 & 0,349 & $5,003^{*}$ & 1,980 \\
\hline P21 & 0,526 & $6,800^{*}$ & 1,980 \\
\hline P31 & 0,174 & $2,044^{*}$ & 1,980 \\
\hline P32 & 0,493 & $5,791^{*}$ & 1,980 \\
\hline
\end{tabular}

Information:

* Significant path coefficient $(\mathrm{p}<0.05)$

Based on the above table we get the following equation:
1) $\mathrm{Y}=0.383 * \mathrm{X} 1+0.232 * \mathrm{X} 2+0.349 * \mathrm{X} 3$
Thit $=5,7243,1164,962$
2) $\mathrm{X} 3=0.174 * \mathrm{x} 1+0.493 * \mathrm{x} 2+\mathrm{e}$
Thit $=2,0355,767$
3) $\mathrm{X} 2=0.526 * \mathrm{X} 1$
Thit $=6,800$

a. The Impactof Transformational Leadership to OCB

The result of path calculation of coefficient direct influence of transformational leadership to OCB $(\mathrm{Py} 1)=0,383$. While the coefficient of indirect path of 0.2732 with the total influence is 0.6562. A positive path coefficient is obtained, indicating that the effect is directly proportional, in the sense that effective transformational leadership will increase OCB. The tcount value obtained is 5.772 , while the ttable value for $\mathrm{dk}=120$ at $\square=0.05$ is 1.980 . tount value $>$ ttable, so Ho is rejected 
and $\mathrm{H} 1$ accepted. This means that transformational leadership has a direct positive and significant effect on OCB.

b. Personality Influence to OCB

From the path calculation of coefficient between the influence of personality to OCB (Py2) got the value of 0.232 . While the indirect line coefficient is 0.172 so the total coefficient of path is 0.404. The positive-valued path coefficient indicates that the improvement of the positive-pointed personality indicates that personality improvement will lead to an increase in OCB. While the value of tcount obtained is 3.142 , while the ttable value for $\mathrm{dk}=74$ at $\square=0.05$ of 1.980 . Thitung value >ttable, so Ho is rejected and $\mathrm{H} 1$ accepted. This means that personality is directly positive and significant to OCB.

\section{c. Job Involvement to OCB}

The direct path coefficient of job involvement to OCB (Py3) is 0.349 . The path coefficient has a positive value which indicates that if job involvement is improved it will be followed by an increase in OCB. The tcount value obtained is 5,003 and ttable value for $\mathrm{dk}=120$ at $\square=0,05$ is 1,980. The value of tcount>ttable indicates that Ho is rejected and $\mathrm{H} 1$ is accepted. This means that job involvement has a direct positive and significant impact on OCB.

d. The Influence of Transformational Leadership to Job Involvement.

The path coefficient of the calculation shows the direct influence of transformational leadership with job involvement $(\mathrm{P} 31)=0.174$. The indirect path coefficient is: 0.174 with the total coefficient of the path is: 0.433 . The acquisition of a positive path coefficient signifies that when the transformational leadership is improved it will be followed by the increasing of job involvement. The tcount obtained is 2.044 , and the ttable value for $\mathrm{dk}=120$ at $\square=0.05$ is 1.980 . Thitung value $>$ table, so Ho is rejected and $\mathrm{H} 1$ accepted. This implies that transformational leadership has a direct positive effect and a significant effect on job involvement.

e. The Influence of Personality toJob Involvement

From result of calculation of path coefficient of personality influence to job involvement (P32) got value equal to 0,493. A positive value coefficient indicates that when the dimensions of the personality are applied it will have an impact on increasing employment engagement. The value of tcount obtained is 5,791 , whereas ttable value for $\mathrm{dk}=120$ at $\square=0,05$ equal to 1,980 . Thitung value >ttable, so Ho is rejected and $\mathrm{H} 1$ accepted. This means that personality has a direct positive and significant effect tojob involvement.

f. The Influence of Transformational Leadership to Personality

The path coefficient of direct influence of transformational leadership to personality (P21) is 0,526. The path coefficient is positive, indicating that the improvement of transformational leadership will be followed by an improvement in personality. While tcount value obtained is 6,800 and ttable value for $\mathrm{dk}=120$ at $\square=0,05$ is 1,980 . The value of tcount $>$ ttable indicates that Ho is rejected and $\mathrm{H} 1$ is accepted. This means that transformational leadership has a direct positive and highly significant effect to personality.

Path coefficient and $t$ arithmetic can then be seen in the following path diagram. 


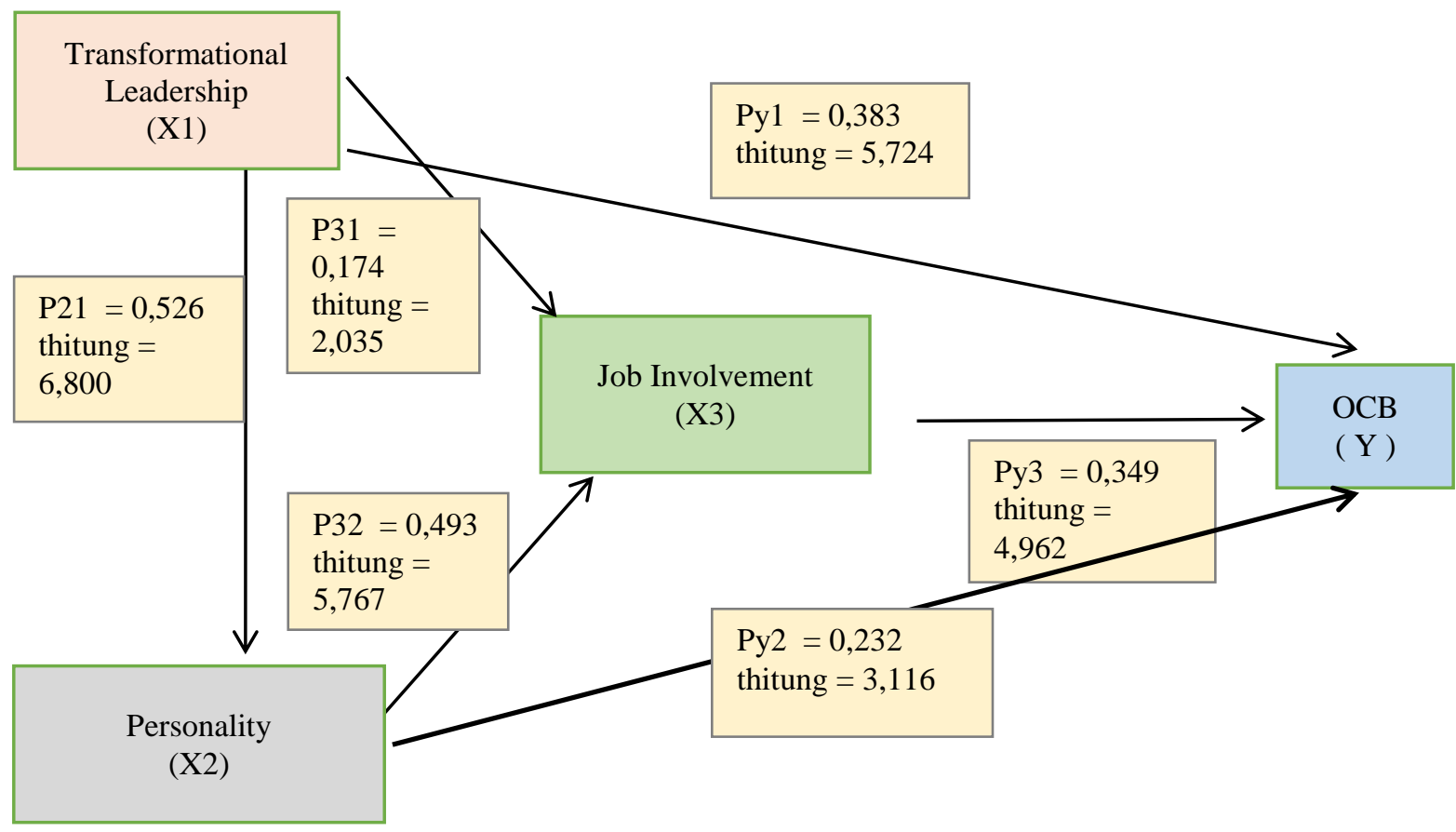

Figure 4.5Path Coefficient and Tcount The Influence of Transformational Leadership, Personality and Job Involvement to OCB

In addition to the direct influence of transformational leadership variables, Personality, job involvement to OCB there is also an indirect influence of the transformational leadership of OCB. These indirect effects can be seen in the table below:

Table 4.13Indirect Influence and Total Influence

\begin{tabular}{|c|c|c|c|}
\hline & indirect Influence & direct Influence & Total Influence \\
\hline $\mathrm{X} 1$ & 0 & \multirow{4}{*}{0.383} & \multirow{4}{*}{0.656} \\
\hline X1 melalui X3 & $\begin{array}{l}0.174 * 0.349= \\
0.060726\end{array}$ & & \\
\hline $\mathrm{X} 1$ melalui X2 & $\begin{array}{l}0.526 * 0.232= \\
0.122\end{array}$ & & \\
\hline $\begin{array}{l}\text { X1 Melalui X2 } \\
\text { dan X3 }\end{array}$ & $\begin{array}{l}0.526 * 0.493 * 0.349= \\
0.0905\end{array}$ & & \\
\hline
\end{tabular}

The table above describe indirect influence $\mathrm{X} 1$ to $\mathrm{Y}$ through $\mathrm{X} 3$ is equal to 0.06 , whereas the indirect effect of $\mathrm{X} 1$ through $\mathrm{X} 2$ is equal to 0.122 , and the indirect effect of $\mathrm{X} 1$ through $\mathrm{X} 2$ and $\mathrm{X} 3$ is 0.090 so that the indirect effect of 0.273 , when summed with the influence Direct which amounted to 0.383 then the effect of total $\mathrm{X} 1$ to $\mathrm{Y}$ is equal to 0.656 this shows that the leadership transformational give a significant influence on OCB officials Echelon IV Directorate General Teachers and Education Personnel Ministry of Education and Culture.

From the calculation of LISREL also obtained the probability value of Chi Square and RMSEA to test the accuracy of the model. The value of significance or $p$ value for Chi Square is $1,000>0,05$ and RMSEA $(0,000)<0,08$. These results indicate that the theoretical model tested has represented or corresponds to the structure of equations based on empirical data. Thus the results obtained from this study fit (fit) with the theory that became the basis for building theoretical model of this study. 


\section{DISCUSSION}

The results of this study prove that transformational leadership has a direct positive and significant impact on OCB. This suggests that transformational leadership is very important and OCB must be improved. This empirical fact is inseparable from the practical reality that every organization needs strong leadership in order for the organization to survive and grow. Mostly style of leadership style is transformational leadership, characterized by a strong self-identification, the creation of a shared vision for the future, and the relationship between leader and follower based on something more than merely a reward for obedience. The transformational leader defines the need for change, creates a new vision, mobilizes a commitment to execute a vision and transforms followers at both the individual and organizational levels. The leader's ability to articulate an attractive vision for the future is a key element of transformational leadership. Thus transformational leadership reflects a person's capability in influencing, motivating, managing activities and interactions among individuals, and enabling others to build a vision and confidence so as to contribute to the achievement of organizational goals, through the influence of idealism, inspirational motivation, stimuli, and individual considerations. Leaders who demonstrate such leadership behaviors can inspire and stimulate subordinates so willingly do the extra work that reflects OCB, that is, actions that are conducted continuously and exceed the standards required by the organization that can contribute positively to the development and effectiveness of the organization. According to the Organ as quoted by Tschannen-Moran, OCB is implemented in the form of mutual interest, prudence, sportsmanship, obedience, and wisdom. The results of Meihami, Varmaghani, and Meihami also show that transformational leadership has a significant effect on OCB, especially altruism, prudence, and virtue. Similarly, the results of Kian and Tui's research also proved that transformational leadership has a significant effect on OCB. This means that the results of this study are appropriate and therefore confirm the results of previous studies on the influence of transformational leadership on OCB, with the research setting on the echelon IV officials of the Directorate General of teacher and education personnelMinistry of Education and Culture RI.

The results of this study also proves that personality has a direct positive and significant effect on OCB. This shows that personality is important for growing OCB. This empirical fact is inseparable from the existence of personality as a specific characteristic inherent in a person. According to Ciccarelli and Meyer, personality is a unique and relatively stable way of thinking, feeling, and acting. In organizational life, the way of thinking, feeling, and acting is very important, both for individual members of organizations and organizations. Thinking can reflect a person's way of solving problems, feels able to reflect responsiveness to the various things within the organization, while acting is a real form of the mind and attitude. Personality can be manifested in friendliness, toughness, trustworthiness, openness to experience, and adjustment. If a person has five dimensions it is in good condition then it is a capital for him to be able to do things that go beyond the boundaries of targets and standards of work or commonly called OCB. OCB is a continuous action that exceeds the standards required by an organization that can contribute positively to the development and effectiveness of the organization, manifested in the form of mutual interest, prudence, sportsmanship, adherence, and prudence. The results of Judge's research, et al. Also proves that personality has an effect on OCB. This means that the results of this study are appropriate and therefore confirm the results of previous research on the influence of personality on OCB, with research setting on echelon IV officials of Directorate General of teacher and education personnelMinistry of Education and Culture RI.

The results of this study also proves that job involvement has a direct positive and highly significant effect on OCB. This shows that employment engagement is very important for OCB. This empirical fact is inseparable from the dynamics of organizational life, including the government organization of the work unit of Ministry of Education and Culture, which requires the involvement of employees and their officials. Job involvement, according to Macey and Schneider, refers to the positive feelings that employees feel related to their work and the motivation and effort they provide 
in the work. Job involvement can be reflected in active participation in work, showing work is the main thing, and assuming that work is something that is important to his self-esteem. Employees with high employment will tend to work beyond the standards set by the organization or commonly called OCB, that is, actions that are carried out continuously and exceed the standards required by the organization that can contribute positively to the development and effectiveness of the organization, manifested in the form Attach importance to common interests, prudence, sportsmanship, obedience, and wisdom. Research Rashidi, Gheisari, and Farokhian, Nwibere and Ueda also proved that job involvement has a positive and significant effect on OCB. This means that the results of this study are appropriate and therefore confirm the results of previous studies on the effect of job involvement on OCB, with the research setting on the echelon IV officials of the Directorate General of teacher and education personnelMinistry of Education and Culture RI.

The results of this study also proves that transformational leadership has a direct positive and highly significant effect on job involvement. This suggests that transformational leadership is essential to spur employment engagement. This empirical fact can not be separated from the existence of transformational leadership which in reality dynamics of organizational life is very necessary, especially to overcome and anticipate complexity of organizational problem. Transformational leadership is characterized by a strong self-identification, the creation of a shared vision for the future, and the relationship between leader and follower based on something more than merely a reward for obedience. Transformational leaders can define the need for change, create new visions, mobilize a commitment to exercise vision and transform followers at both the individual and organizational levels. Transformational leadership reflects a person's ability to influence, motivate, manage activities and interactions among individuals, and enable others to build a vision and confidence so as to contribute to the achievement of organizational goals, through the influence of idealism, inspirational motivation, stimuli, and individual considerations. Leaders who demonstrate such leadership behavioral patterns can inspire and stimulate volunteers to be actively involved in work. According to Macey and Schneider, work engagement refers to the positive feelings that employees feel about work and the motivations and efforts they provide in the work, which can be manifested in active participation in work, showing work is the main thing, and assuming that work is something Important for his pride. The results of Nazem and Mozaiini's research in India also proved that leadership has a significant effect on employment engagement. This means that the results of this study are appropriate and therefore confirm the results of previous studies on the influence of transformational leadership on job involvement, with the research setting on the echelon IV officials of the Directorate General of teacher and education personnelMinistry of Education and Culture RI.

The results of this study also proves that personality has a direct positive and significant effect on job involvement. This shows that personality is very important for work engagement. This empirical fact is inseparable from the existence of personality as a specific characteristic of a person who is unique and relatively stable in thinking, feeling, and acting. This way of thinking, feeling, and acting is very important for employees and organizations. The way of thinking can determine the quality of the solution of various problems, feel able to determine the positive attitude and responsive to various problems that arise, and act is a concrete form of the positive thoughts and attitudes. Personality can be manifested in friendliness, toughness, trustworthiness, openness to experience, and adjustment. If the five dimensions are in good condition then it can encourage someone engaged more actively in various job activities. According to Macey and Schneider, work engagement refers to the positive feelings that employees feel about work and the motivations and efforts they provide in the work, which can be manifested in active participation in work, showing work is the main thing, and assuming that work is something Important for his pride. The results of Liao and Lee and Eswaran and Islam also proved that personality influences job involvement. This means that the results of this study are appropriate and therefore confirm the results of previous studies on the 
influence of personality on job involvement, with research setting on echelon IV officials Directorate General of teacher and education personnelMinistry of Education and Culture.

The results of this study also proves that transformational leadership has a direct positive and highly significant effect on the personality. This shows that transformational leadership is very important for personality. This empirical fact is inseparable from the existence of transformational leadership that in reality the dynamics of the organization is not only expected to help the effectiveness of the organization in achieving its objectives, but more than that it is also expected to encourage the formation of better employees (subordinates). Transformational leadership is characterized by a strong self-identification, the creation of a shared vision for the future, and the relationship between leader and follower based on something more than merely a reward for obedience. The transformational leader defines the need for change, creates a new vision, mobilizes a commitment to execute a vision and transforms followers at both the individual and organizational levels. The leader's ability to articulate an attractive vision for the future is a key element of transformational leadership. Transformational leadership reflects a person's ability to influence, motivate, manage activities and interactions among individuals, and enable others to build a vision and confidence so as to contribute to the achievement of organizational goals, through the influence of idealism, inspirational motivation, stimuli, and individual considerations. Leaders who demonstrate such behavioral patterns of leadership can inspire, stimulate and motivate the volunteers to make their personality better. According to Ciccarelli and Meyer, personality is a unique and relatively stable way of thinking, feeling, and acting. In this case, the example of the leader can improve the way in which subordinates think, feel and act, which manifests in terms of hospitality, toughness, trustworthiness, openness to experience, and adjustment. Johnson's analysis, et al also shows that leadership positively affects the personality. This means that the results of the study are appropriate and therefore confirm the results of previous research on the influence of transformational leadership on personality, with the research setting on the echelon IV officials of the Directorate General of teacher and education personnelMinistry of Education and Culture.

\section{CONCLUSIONS}

From the elaboration and discussion of the results of research analysis in Chapter IV it can be concluded that the empirical findings of this study are:(1) transformational leadership has a direct positive and significant influence on OCB. The findings indicate if the improvement of transformational leadership can increase OCB echelon IV officials at the Directorate General of teacher and education personnelMinistry of Education and Culture. (2) Personality has a direct positive and highly significant effect on OCB. These findings indicate that personality improvement can improve the OCB of echelon IV officials on the Directorate General of teacher and education personnelMinistry of Education and Culture. (3) Job involvement has a direct positive and highly significant impact on OCB. These findings suggest that improvements in job involvement may increase OCB echelon IV officials on the Directorate General of teacher and education personnelMinistry of Education and Culture. (4) Transformational leadership has a direct positive and highly significant impact on job involvement. These findings indicate that improvements in transformational leadership can increase the involvement of echelon IV officials in the Directorate General of teacher and education personnelMinistry of Education and Culture RI. (5) Personality has a direct positive and significant effect on job involvement. These findings indicate that personality improvement can increase the involvement of echelon IV officials in the Directorate General of teacher and education personnelMinistry of Education and Culture. (6) Transformational leadership has a direct positive and significant effect on the personality. These findings indicate that the improvement of transformational leadership can improve the personality of echelon IV officials on the Directorate General of teacher and education personnelMinistry of Education and Culture. 


\section{REFERENCES}

Aamodt, Michael G. (2013).Industrial / Organizational Psychology: An Applied Approach, Belmont.CA: Thomson Learning, Inc.

André, Rae. (2008).Organizational Behavior: An Introduction to Your Life in Organizations. New Jersey: Pearson Prentice-Hall.

Armstrong, Michael. (2006). A Handbook of Human Resource Management Practice, Tenth edition. Great Britain: Cambridge University Press.

Armstrong, Michael. (2010). Essential Human Resource Management Practice.Great Britain: Kogan Page Limited.

Azwar, Saifuddin. (1999).Psychology Scale Compilation.Yogyakarta: PustakaPelajar. .Reliability and Validity. (2003). Yogyakarta: PustakaPelajar, 2003.

Build, Wilson. (2012).Human Resource Management, Jakarta: Erlangga Publishers.

Bernardin, H. John \& Joyce E. A. Russell. (2013).Human Resource Management.Sixth edition.United State of America: McGraw Hill International Edition.

Bertocci, D.I. (2009).Leadership in Organizations.University Press of America, Inc.

Brannen, J. (2002).Composite Qualitative and Quantitative Research Methods. Yogyakarta: Publisher PustakaPelajar.

Brown, A. (1998).Organizational Culture. Singapore: Prentice Hall.

Byrne, Barbara M. (1998).Structural Equation Modeling with LISREL, PRELIS, and SIMPLIS: Basic Concepts Appcations, and Programing. New Jersey: Lawrence Erlbaum Associates, Inc.

Carver, Charles S. \& Michael F. Scheier. (2008). Perspectives on Personality, Boston: Pearson Education, Inc.

Chourmain, M. A. S. Priest. (2006).Normative Reference of Research for Thesis Writing, Thesis and Dissertation.Jakarta: Al-HaramainPuiblishing House.

Ciccarelli, Saundra K. \& Glenn E. Meyer. (2006).Psychology. New Jersey: Prentice Hall.

Ciulla, Joanne B and James MacGregor Burns Ethics. (2004).The Hearth of Leadership. Westport: An Imprint of Greenwood Publishing Group, Inc.

Daft, Richard L. (2011).Leadership. South-Western: Cengage Learning.

Daft, Richard L. and Dorothy Macrcic. (2008).Management: The New Workplace. United Kingdom: South-Western.

Dougherty, Dreher. (2001).Human Resource Strategy. United States of America: McGraw Hill / Irwin.

Davis, F. R. (2013).Strategic Management. New York: Prentice Hall International Ltd.

Denzin, N. K. and Y. S. Lincols. (2003).Handbook of Qualitative Researc, Thounsands. Oaks: CA: Sage Publications.

Diefendorff, J. M., D. J. Brown, A. M. Kamin, R. G. Lord. (2002)."Examining The Roles of Job Involvement and Work Centrality in Predicting Organizational Citizenship Behavior and Job Performance." Journal of Organizational Bihavior, Vol. 23. pp. 93-108.

Duane Schultz and Sydney Ellen Schult. (2006).Psychology \& Work Today, New Jersey: Pearson Education Inc.

Eugene McKenna. (2006).Business and Psychology: Organizational Behavior.New York: Psychology Press.

Foote, David A. and Thomas Li-Ping Tang. (2008)."Job satisfaction and organizational citizenship behavior (OCB) Does team commitment make a difference in self-directed teams?" Management Decision, Vol. 46 No. 6.

Gibson, J. L., Ivancevich, J. M., Donnelly, J. H., and Konopaske, R. (2009).Organizations: Behavior, Structur, Processes. 11th Edition, New York: McGraw-Hill Irwin.

Greenberg, J. and R. A. Baron. (2008).Behavior in Organization. New Jersey: Prentice Hall, Inc.

Griffin, Ricky W. (2002).Management.Fourth Edition. Boston: Hougton Mifflin Company.

Hughes, Richard L., Robert C. Ginnett and Gordon J. Curphy. (2009).Leadership: Enhancing the Lessons of Experience. New York: McGraw-Hill Companies, Inc.

Jewell, L.N. (1995).Contemproy Industrial / Organizational Psychology, Pacific Grove. California: Cole Publishing Company.

Kerlinger, Fred N. \& Howard B. Lee. (2000).Foundations of Behavioral Research.Forth Worth: Harcourt Collge Publishers.

Kerlinger, Fred N. \&Elazar J. Pendhazur. MultipleRegression Behavioral Research. USA: Holt, Rinehart \& Winston, Inc. 
Konrad, M., et al. (2000)."Sex Differences and Similarities in Job Attribute Preferences: A Meta Analysis." Psycology Bulletin, Vol. 126. pp. 593-641.

Kotter, John P. (2004).Leading Change: Becoming a Pioneer of Change. Jakarta: PT. GramediaPustakaUtama.

Kouzes, James M. and Barry Z Posner. (1999).The Leader Challenge.Batam Center: Interaksa.

Macey, W. H. and B. Schneider. (2008)."The Meaning of Employee Engagement," Industrial and Organizational Psychology, Vol. 1.

Malhotra, N.K. (2010).Marketing Research: An Apllied Orientation.6th edition. Boston: Pearson.

Matindas, R. (1997). Human Resource Management Through the Concept of Ambition, Reality and Effort. Jakarta: PustakaUtamaGrafiti.

McMillan, James H. \& Sally Schumacher. (2006).Research in Education. New Jersey: Pearson.

Nasrudin, AizzatMohd, IntanOsman, and ZainalAriffin Ahmad. (2006).Introduction to Management.Publisher Petama. Kuala Lumpur: Distance Learning Education Center University Sains Malaysia.

Nawawi, Hadari and Martini Hadari. (2006).Social Research Instrument. Yogyakarta: Gajah Mada University Press.

Noe, R. A., John R. H., Barry G., Patrick M. W. 2015. Human Resource Management.Nineth edition. United Kingdom: McGraw Hill Education.

Parker, Jeanette Plauche and Lucy GremillionBegnaud. (2004).Developing Creative Leadership. Westport CT: Libraries Unlimited.

Passer, Michael W. and Ronald E. Smith. (2007).Psychology: The Science of Mind and Behavior. New York: McGraw-Hill.

Pawlik-Kienlen, Laurie. (2007)."Changing Your Personality: When You Change Your Personality Traits, You Change Your Life”.(http://www.w3.org/TR/xhtml1/DTD/xhtml1transitional.dtd).

Podsakoff, P.M., M. Ahearne, and S. B. McKenzie. (1997)."Organizational Citizenship Behavior and the Quantity and Quality of Work Group Performance," Journal of Applied Psychology, Vol. 82, 1997, 262 - 270.

Reinhartz, J. and Beach, D. M. (2004).Educational Leadership Changing Schools, Changing Role. New York: Pearson Prentice-Hall.

Robbins, S. P. and T. A. Judge. (2013).Organizational Behavior: Concept, Controvesies and Application, New Jersey: Prentice Hall.

Robbins, Stephen P. and Mary Coutler. (2010).Management.Tenth Edition.The translation of Bob Sabran and DevriBarnadiPutera. Jakarta: Erland.

(2016). Management.Thirteenth edition.United States of America: Pearson Educated Limited.

Santrock, John S. (2008).Educational Psychology. New York: McGraw-Hill.

Sloat, K. C. M. (2000). "Organizational citizeship: Does your firm inspire to be 'Good Citizenship'?" Professional Safety, Vol. 44 (4), pp. 20-23.

Sommers, S. M., S.H. Bae and F. Luthans. (2000). "Organizational Commitment Across Culture: The Impact of Antecedents on Korean Employees." Human Relation, Vol. 49, pp. 977-993.

Starling, Grover. (2008).Managing the Public Sector. United States of America: Thomson Wadsworth.

Strauss, George and Leonard R. Sayles. (1990).Personnel Management: Human Facets In Organization. Jakarta: Reader BinamanPressindo.

Terry, George R., and Leslie W. Rue. (2010).Principles of Management.Translation G. A. Ticoalu. Jakarta: PT. Earth Script.

Tschannen-Moran, M. (2004)."Fostering organizational citizenship in schools: transformational leadership and trust." Journal of Educational Administration, Chapter 6, pp. 1-36.

Umar, Husayn. (2006).Marketing \& Consumer Behavior Research. Jakarta: PT. GramediaPustakaUtama cooperation Jakarta Business Research Center (JBRC).

Van Wagner, Kendra. (2008).What Is Personality? (Http://www.about.com).p. 1.

Waite, Mitchell R. (2007).Fire Service Leadership: Theories and Practices. Sudbury. MA: Jones \& Bartlett Publishers.

Wirawan. (2002).KapitaSelekta: Leadership Theory, Introduction to Practice and Research. Jakarta: YayasanBangunIndonesia and Uhamka Press. 
Yukl, Gary. (2010).Leadership in Organizations, Seventh Edition. New Jersey: Personn Education, Inc.

Zangaro, G. A. (2001)."Organizational Commitment: A Concept Analysis," Nursing Forum, Vol. 36. 